\title{
Effect of habitat isolation on genetic divergence of bank vole populations
}

\author{
Michał KOZAKIEWICZ and Joanna KONOPKA
}

\begin{abstract}
Kozakiewicz M. and Konopka J. 1991. Effect of habitat isolation on genetic divergence of bank vole populations. Acta theriol. 36: $363-367$.

The frequency of 12 non-metric skull variants was used to evaluate the effect of habitat isolation on genetic structure of bank vole populations. Genetic differences were compared between bank voles inhabiting an isolated patch of wood and animals caught in large, continuous forest. "Bottleneck" effect was suggested as a possible cause of the differences found. Results are discussed in terms of genetic variability within a metapopulation.
\end{abstract}

Warsaw University, Institute of Zoology, Department of Ecology, Krakowskie Przedmieście 26/28, 00-918 Warsaw, Poland

Key words: habitat isolation, genetic divergence, Clethrionomys glareolus

\section{Introduction}

Fragmentation of the landscape produces a series of habitat patches separated from one another by matrix of contrasting habitats. It often leads to the division of animal populations living there into more or less separated units or subpopulations. A group of inter-connected patch populations can form a metapopulation (Levins 1970). Local extinctions of subpopulations occupying separate patches of habitat as well as dispersal of individuals between patches seem to be of highest importance for demographic and, especially, for genetic features of the whole metapopulation (e.g. Merriam et al. 1989). Many recent papers have analysed gene flow across fragmented landscapes and gene frequency gradients (e.g. Soule 1987) and effects of inbreeding and genetic drift in fragmented populations (Boecklen and Bell 1984, Vrijenhoek 1985, Berry 1986).

However, according to many authors (Chepko-Sade et al. 1987, Saunders et al. 1991 and others), the rates of genetic change in isolated populations still require study, as does the question of changes in genetic variability within metapopulation.

The aim of the present study was to evaluate the effect of habitat isolation on phenetic structure within a metapopulation of bank voles Clethrionomys glareolus (Schreber, 1780) by analysing the expression of non-metric skull variants.

\section{Methods}

The studies were carried out in June 1989 in the vicinity of Urwitałt near Mikołajki, north Poland. Bank voles were snap-trapped in three separated trapping sites. The first - "Woodlot" site - was a small (1.35 ha) 
wooded patch surrounded and isolated by meadows. The second ("Forest") and third ("Control") trapping sites were situated inside the large, continuous forest. The distance between the "Woodlot" site and the nearest site in the forest ("Forest" site) was about $300 \mathrm{~m}$ and the same distance separated two forest sites ("Forest" and "Control" ones).

The frequency of 12 non-metric (binary, present/absent) skull variants is given in Table 1 . The analysed skull variants were independent (not correlated to each other) and their frequencies were not correlated with the age or sex of individuals. Statistical analysis followed Grewal-Smith as modified by Sjøvold (1977). The mean measure of divergence (MMD) and standard deviation (SD MMD) were calculated for all three pairs of compared groups of animals, from the frequency of occurrence of 12 non-metric skull variants being analysed.

Table 1. Percentage frequencies of skull variants. $n=$ number of skulls analysed.

\begin{tabular}{llrr}
\hline & \multicolumn{3}{c}{ Locality } \\
\cline { 2 - 4 } Skull variants & $\begin{array}{c}\text { Woodlot } \\
\mathrm{n}=38\end{array}$ & $\begin{array}{c}\text { Forest } \\
\mathrm{n}=32\end{array}$ & $\begin{array}{c}\text { Control } \\
\mathrm{n}=28\end{array}$ \\
\hline 1. Maxillary for. II single & 63.2 & 50.0 & 37.0 \\
2. Maxillary for. I absent & 35.1 & 21.9 & 66.7 \\
3. For. ovale single & 86.78 & 3.3 & 56.5 \\
4. For. palat. min. ant. present & 58.8 & 10.0 & 8.3 \\
5. For. palat. min. post. present & 86.7 & 81.5 & 68.4 \\
6. For. hypoglossi single & 74.3 & 30.0 & 3.6 \\
7. Post. margin of nas. bones. convex & 63.2 & 9.4 & 17.2 \\
8. Post. margin of nas. bones V-shaped & 13.2 & 68.8 & 62.1 \\
9. Frontoparietal suture V-shaped & 26.3 & 6.3 & 3.5 \\
10. Accesory frontal for. present & 76.7 & 90.0 & 96.0 \\
11. Ethmoid for. double & 80.7 & 72.4 & 70.0 \\
12. Supra-dentary for. present & 67.7 & 41.9 & 34.6 \\
\hline
\end{tabular}

The mean measure of divergence (MMD) is expressed by the equation:

$$
\mathrm{MMD}=\frac{1}{r} \sum\left(\Theta_{1}-\Theta_{2}\right)^{2}-v
$$

where $r$ is the number of variant characters examined, $\Theta$ is the angular transformation in radians of relative frequency of variants $p,[\Theta=\arcsin (1-2 p)]$. The expression $v$ is a correction for difference in sample size and is:

$$
v=\frac{1}{\left(n_{1}+0.5\right)}+\frac{1}{\left(n_{2}+0.5\right)}
$$

where $n$ is the sample size. Statistical significance of differences between each two groups was tested by means of standard deviation of MMD (SD MMD), which is expressed by the equation:

$$
\mathrm{SD} M M D=\sqrt{\text { var. MMD }}=\sqrt{\frac{1}{r^{2}} \sum 4 v\left(\Theta_{1}-\Theta_{2}\right)^{2}-2 v^{2}}
$$

where: $v=\frac{1}{n_{1}}+\frac{1}{n_{2}}$ and other symbols are the same as in MMD equation (Sjøvold 1977). 
Where the value of MMD is greater than double SD MMD, the two compared groups are significantly divergent (for details see Markowski and Sikorski 1987). The measure of uniqueness (MU) was also calculated for each group of voles, as the sum of all mean measures of divergence used in comparing the group.

\section{Results}

It was found that MMD differences were significant between: "Woodlot" and "Forest" and between "Woodlot" and "Control", but not between "Forest" and "Control" (both continuous forest sites) (Table 2). The "Woodlot" group of bank voles (isolated by habitat) differed genetically from both groups of animals inhabiting continuous forest.

This "Woodlot" group also had the greatest measure of uniqueness (MU) indicating that voles isolated in wooded habitat patch differed most from all other groups (Table 2).

Table 2. Mean measure of divergence (MMD) and measure of uniqueness (MU) between studied groups animals. Standard deviations (SD MMD) are given in parentheses.

\begin{tabular}{lccc}
\hline & Forest & Woodlot & MU \\
\hline Control & 0.0881 & $\begin{array}{c}0.5596^{*} \\
(0.2053)\end{array}$ & 0.6476 \\
& $(0.1026)$ & $0.4072 *$ & 0.4952 \\
Forest & & $(0.0851)$ & \\
& & & 0.9668 \\
Woodlot & & \\
\hline * - statistically significant divergence.
\end{tabular}

\section{Discussion}

According to many authors, the expression of these non-metric skull variants is under genetic control, which makes it possible to use them to asses genetic divergence within and between populations (Markowski and Sikorski 1987, Bauchau 1988).

Our results suggest that observed genetic divergence of bank vole population within the whole study area can result from habitat fragmentation and isolation of local habitat patch populations. Population density of bank voles, especially in isolated patches of habitats, shows a marked spring decrease, with the minimum far less than 10 individuals per hectare (Kozakiewicz 1985). Thus, early spring populations inhabiting small and isolated patches of habitat are reduced to only a few individuals. As a result a very small number of breeding individuals can act as founders for later population growth. Species isolated in habitat patches may go through such genetic "bottleneck" effects regularly (Bauchau and Le Boulengé 1991, Saunders et al. 1991). The genetic peculiarity of the "Woodlot" patch population of bank voles could have developed in this way. Such "bottleneck" or "founder" effects in small mammal populations have been described by Corbet (1963), Sikorski (1982), Sikorski and Bernshtein (1984), Bauchau (1987), Bauchau and Le Boulengé (1991). 
In the present study only overwintered animals and representatives of the first spring generation were caught in the late spring. However, later in the season, transfer of individuals between patch populations may decrease or even remove the "bottleneck" effects (Boecklen and Bell 1987).

On the other hand, even occasional migration of genes between subpopulations combined with random losses of the alleles in each subpopulation ("bottleneck" effect) favors the occurrence of high genetic variability within the whole metapopulation (Chepko-Sade et al. 1987). It is because new gene combinations are constantly being formed and the loss of alleles from the metapopulation as a whole is not frequent. It might be expected that when a new, adaptive gene combination appears, it can become established by selection in a small subpopulation far more quickly than in a large population by mass selection. The favorable new genetic combination can be introduced to other subpopulations by interpatch dispersing individuals until it becomes widespread in the entire metapopulation. Thus, the small size of discrete subpopulations and occasional transfer of individuals between subpopulations can induce temporal genetic variation within the patches as well as increased genetic variability in the whole metapopulation in the longer term.

Acknowledgements: Our thanks are due to Professor Z. Pucek and Dr. M. Sikorski (Mammal Research Institute, P.A.S., Białowieża, Poland) for their attention to our work and advice on methods. We are grateful to Dr. G. Merriam, Professor of Biology (Carleton University, Ottawa, Canada) for his critical reading of the manuscript. This research was supported by Research Programm 04.10.

\section{References}

Bauchau V. 1987. Effect of habitat patchiness on ecological and genetic structure of woodland rodent populations. [In: Report of the First European Meeting "The Rodent and its Environment"]. Mammalia 51: $468-469$.

Bauchau V. 1988. Non-metrical variation in wild mammals: a bibliography. Mammal Rev. 18: 195 - 200.

Bauchau V. and Le Boulengé E. 1991. Population biology of woodland rodents in a patchy landscape. [In: Le Rongeur et l'Espace. M. Le Berre and L. Le Guelte, eds]. R. Chabaud, Paris: 275 - 283.

Berry R. J. 1986. Genetics of insular populations of mammals, with particular reference to differentiation and founder effects in British small mammals. Biol. J. Linn. Soc. 28: 205 - 230.

Boecklen W. J. and Bell C. W. 1987. Consequences of faunal collapse and genetic drift for the design of nature reserves [In: Nature conservation: the role of remnants of native vegetation. D. A. Saunders, G. W. Arnold, A. A. Burbidge and A. J. M. Hopkins, eds]. Surrey Beatty and Sons, Chipping Norton: $141-149$.

Chepko-Sade B. D., Shields W. M., Berger J., Tang Halpin Z., Jones W. T., Rogers L. L., Rood J. P. and Smith A. T. 1987. The effects of dispersal and social structure on effective population size. [In: Mammalian dispersal patterns. The effects of social structure on population genetics. B. D. Chepko-Sade and Z. Tang Halpin, eds]. The University of Chicago Press, Chicago, London: 287 - 321.

Corbet G. B. 1963. An isolated population of the bank vole Clethrionomys glareolus with aberrant dental pattern. Proc. zool. Soc. Lond. 140: 316 - 319.

Kozakiewicz M. 1985. The role of habitat isolation in formation of the structure and dynamics of the bank vole population. Acta theriol. 30: $193-209$.

Levins R. 1970. Extinction. [In: Some mathematical questions in biology. Lectures on mathematics in the life sciences. M. Gerstenhaber, ed.]. American Mathematical Society, Providence, R.I., USA, 2: 77 - 107.

Markowski J. and Sikorski M. D. 1987. Use of non-metrical traits in population study. Prz. zool. 31: 7 - 23. [In Polish with English summary] 
Merriam G., Kozakiewicz M., Tsuchiya E. and Hawley K. 1989. Barriers as boundaries for metapopulations and demes of Peromyscus leucopus in farm landscapes. Landscape Ecology 2: $227-235$.

Saunders D. A., Hobbs R. J. and Margules C. R. 1991. Biological consequences of ecosystem fragmentation: a review. Conserv. Biol. 5: $18-32$.

Soulé M. E. [ed.] 1987. Viable populations for conservation. Cambridge University Press, Cambridge: 1 - 189.

Sikorski M. 1982. Non-metrical divergence of isolated populations of Apodemus agrarius in urban areas. Acta theriol. 27: $169-180$.

Sikorski M. and Bernshtein A. D. 1984. Geographical and intrapopulation divergence in Clethrionomys glareolus. Acta theriol. 29: $219-230$.

Sjøvold T. 1977. Non-metrical divergence between skeletal populations. Ossa 4: Suppl. 1: 1- 133.

Vrijenhoek R. C. 1985. Animal population genetics and disturbance: the effects of local extinctions and recolonizations on heterozygosity and fitness. [ In: The ecology of natural disturbance and patch dynamics. S. T. A. Pickett and P.S. White, eds]. Academic Press, New York: $266-286$.

Received 17 June 1991, accepted 18 September 1991.

Acta Theriologica $36(3-4): 367$ - 368, 1991.

\section{BOOK REVIEW}

\section{Ecology of mammalian communities}

Patterns in the structure of mammalian communities. D. W. Morris, Z. Abramsky, B. J. Fox and M. R. Willig, eds. Texas Tech University, The Museum, Special publications no. 28, Texas Tech. Univ. Press, Lubbock, 1989, 266 pp.: ISBN 0-89672-173-6.

The book is a result of a symposium under the same title which took place within the 4th ITC in Edmonton in 1985. It is a collection of original articles concerning, in a broad sense, the ecology of mammalian communities, prepared by 26 authors from 7 countries. It contains both theoretical papers and the results of experimental research. The subject of these researches were various taxonomic groups of mammals and species of various life-history strategies inhabiting all kinds of habitats on almost all continents. The highest number of data, however, concerns rodents. The focus of the authors' interests were both the distribution and abundance of species in terms of geography, and the use of microhabitats, or the strategy of foraging by individual animals. Furthermore, they were interested in ecological photographs of current competitive processes, as well as in the analysis of paleontological evidence of the stability and repetitiveness of community structure over millions of years of mammal evolution.

The first part concerns habitat selection. In it the theoretical models of such selection and their application in the research of community organization were discussed (M. L. Rosenzweig). It was shown that the spatial variation of rodent density in the temperature and boreal zones forests was the effect of the spatial diversity of food abundance in the habitats (D. W. Morris). The habitat selection and the level of desert rodent density depend on the seasonal changes of food abundance resulting from the use of herbicides and the variable precipitations (W. G. Whitford, Y. Steinberger). The habitat tolerance and the niche breadth of the temperate zone rodents can also depend on the density and the population structure, as well as on the density of the competing species (W. I. Montgomery). The distribution of bats on the territory of various plant formations in Venezuela indicates that most of the species are characterized by a considerable habitat tolerance. There is, however, a clear connection between a given type of vegetation and the distribution of insectivorous species inhabiting tropical forests (M. R. Willig, M. A. Mares).

The second part is devoted to the interspecific dependences and interference. The granivorous rodents from semidesert regions of North America belong to the most frequently studied guilds of related and ecologically similar species. They are characterized by both a significant diversity and an impressive variation in the species composition, this latter not only on the historical and geographical but on the local and seasonal scales as well. 